Supporting Information

\title{
Engineering One-Dimensional AuPd Nanospikes for Efficient Electrocatalytic Nitrogen Fixation
}

Shuli Yin, Songliang Liu, Hugang Zhang, Shiqian Jiao, You Xu, Ziqiang Wang, Xiaonian Li,

Liang Wang and Hongjing Wang*

State Key Laboratory Breeding Base of Green-Chemical Synthesis Technology, College of Chemical Engineering, Zhejiang University of Technology, Hangzhou, Zhejiang 310014, P. R. China Corresponding author’E-mail: hjw@zjut.edu.cn. 


\section{Materials and chemicals}

Poly(styrene)-b-poly(ethylene oxide) $\left(\mathrm{PS}_{3800}-\mathrm{b}-\mathrm{PEO}_{5000}\right)$ was obtained from Polymer Source, Inc. 1-naphthol, chloroauric acid trihydrate $\left(\mathrm{HAuCl}_{4} \cdot 3 \mathrm{H}_{2} \mathrm{O}\right)$, Nafion 117, sodium tetrachloropalladate

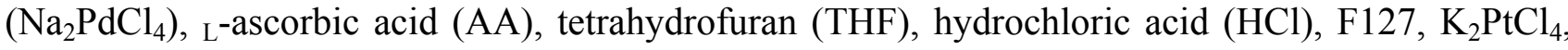
$\mathrm{RuCl}_{3}, \mathrm{~K}_{3} \mathrm{RhCl}_{6}$ and $\mathrm{Na}_{2} \mathrm{IrCl}_{6}$ were ordered from Aladdin Industrial Corporation (Shanghai, China). Sodium sulfate $\left(\mathrm{Na}_{2} \mathrm{SO}_{4}\right)$, sodium hydroxide $(\mathrm{NaOH})$, sodium salicylate, sodium hypochlorite solution $(\mathrm{NaClO})$, L-ascorbic acid sodium salt $\left(\mathrm{C}_{6} \mathrm{H}_{7} \mathrm{NaO}_{6}\right)$, sodium nitroferricyanide dihydrate $\left(\mathrm{C}_{5} \mathrm{FeN}_{6} \mathrm{Na}_{2} \mathrm{O} \cdot 2 \mathrm{H}_{2} \mathrm{O}\right)$, ammonium chloride $\left(\mathrm{NH}_{4} \mathrm{Cl}\right)$, ammonium chloride- ${ }^{15} \mathrm{~N} \quad\left({ }^{15} \mathrm{NH}_{4} \mathrm{Cl}\right)$, p-dimethylamino benzaldehyde $\left(\mathrm{C}_{9} \mathrm{H}_{11} \mathrm{NO}\right)$, ethanol $\left(\mathrm{C}_{2} \mathrm{H}_{5} \mathrm{OH}\right)$ and sulfuric acid $\left(\mathrm{H}_{2} \mathrm{SO}_{4}\right)$ were purchased from Beijing Chemical Works. Ultrapure water $(18.2 \mathrm{M} \Omega \mathrm{cm})$ was used in all experiments. All reagents were used as received without further purification.

\section{Characterization}

The particle size and morphology of the samples were characterized by using a ZEISS Gemini 500 scanning electron microscope (SEM) operated at $5 \mathrm{kV}$. Transmission electron microscopy (TEM), and high-resolution TEM (HRTEM) were performed with a TalosS-FEG operated at $200 \mathrm{kV}$. The phase and crystallinity of the samples were studied by X-ray diffraction (XRD, PANalytical X'Pert Powder) using $\mathrm{Cu} \mathrm{Ka}$ radiation. X-ray photoelectron spectroscopy (XPS) measurements were conducted on the Thermo escalab 250Xi instrument using Al $K \alpha$ radiation $(h v=1486.6 \mathrm{eV})$ operated at 150 W. ${ }^{1} \mathrm{H}$ nuclear magnetic resonance $\left({ }^{1} \mathrm{H}-\mathrm{NMR}\right)$ spectra were recorded on a superconducting-magnet NMR spectrometer (Bruker AVANCE III HD 500 MHz).

\section{Product Determination}

The ammonia $\left(\mathrm{NH}_{3}\right)$ concentration after the nitrogen reduction reaction (NRR) test was estimated by 
the indoxyl blue method. After $2 \mathrm{~h}$ of chronopotentiometric measurement, $4 \mathrm{~mL}$ of electrolyte after electrolysis was mixed with $0.5 \mathrm{~mL}$ of $0.32 \mathrm{M} \mathrm{NaOH}$ solution containing $0.4 \mathrm{M}$ sodium salicylate, $50 \mu \mathrm{L}$ of $0.05 \mathrm{M} \mathrm{NaClO}$ solution containing $0.75 \mathrm{M} \mathrm{NaOH}$, and $50 \mu \mathrm{L}$ of $1 \mathrm{wt} \% \mathrm{C}_{5} \mathrm{FeN}_{6} \mathrm{Na}_{2} \mathrm{O}$ for $1 \mathrm{~h}$. After being left in the dark for $1 \mathrm{~h}$ the mixed solution was measured using the UV-vis spectrophotometer by a TU-1900 spectrophotometer, and calibrate the produced indoxyl blue by the absorbance at $680 \mathrm{~nm}$ wavelength. In order to estimate the $\mathrm{NH}_{3}$ concentration, a series of standard $\mathrm{NH}_{4} \mathrm{Cl}$ solution were used to calibrate the concentration absorbance curve.

The $\mathrm{NH}_{3}$ yield $\left(/_{\mathrm{NH} 3}\right)$ and Faradaic efficiency $(\mathrm{FE})$ were calculated as follows:

$$
\begin{aligned}
& r_{\mathrm{NH}_{3}}=\left(c_{\mathrm{NH}_{3}} \times V\right) / t \times m \\
& \mathrm{FE}=3 \mathrm{~F} \times n_{\mathrm{NH}_{3}} / Q
\end{aligned}
$$

where $c_{\mathrm{NH}_{3}}\left(\mu \mathrm{g} \mathrm{mL}^{-1}\right)$ is $\mathrm{NH}_{3}$ concentration, $V(\mathrm{~mL})$ is volume of the electrolyte, $t(\mathrm{~h})$ is electrolysis time, $m(\mathrm{mg})$ is mass catalyst mass, $\mathrm{F}$ is Faraday constant $\left(96485 \mathrm{C} \mathrm{mol}^{-1}\right), n_{\mathrm{NH}_{3}}(\mathrm{~mol})$ is $\mathrm{NH}_{3}$ concentration and $Q(\mathrm{C})$ is total electric quantity during each NRR process.

\section{Determination of $\mathrm{N}_{2} \mathrm{H}_{4}$}

$\mathrm{N}_{2} \mathrm{H}_{4}$ was determined by Watt and Chrisp method. In short, $5 \mathrm{~mL}$ of electrolyte was mixed with 5 $\mathrm{mL}$ of coloring reagent for $20 \mathrm{~min}$. The color reagent was prepared by mixing $5.99 \mathrm{~g}$ of p-(dimethylamino) benzaldehyde, $300 \mathrm{~mL}$ of ethanol, and $30 \mathrm{~mL}$ of concentrated $\mathrm{HCl}$. The $\mathrm{N}_{2} \mathrm{H}_{4}$ produced was measured using an absorbance at $455 \mathrm{~nm}$.

\section{${ }^{15}$ Isotopic Labeling Experiment}

${ }^{15} \mathrm{~N}_{2}$ was used as the feed gas for the isotopic labeling experiment. In this experiment, ${ }^{15} \mathrm{~N}_{2}$ was electrolyzed at $-0.3 \mathrm{~V}$ for $10 \mathrm{~h}$ and then $10 \mathrm{~mL}$ of electrolyte was taken out, and $\mathrm{pH}$ was adjusted to $1 \sim 2$ by adding $1 \mathrm{M} \mathrm{H}_{2} \mathrm{SO}_{4}$. Then, the solution was concentrated to $1 \mathrm{~mL}$, followed by adding $0.1 \mathrm{~mL}$ 
of $\mathrm{D}_{2} \mathrm{O}$ as an internal standard. The produced $\mathrm{NH}_{3}$ was quantified using ${ }^{1} \mathrm{H}-\mathrm{NMR}$ measurements.

\section{Colorimetric detection of $\mathrm{NO}_{3}{ }^{-}$}

The detection of $\mathrm{NO}_{3}{ }^{-}$was based on the reported literature. ${ }^{1}$ The $\mathrm{NO}_{3}{ }^{-}$standard solution was prepared as follows ( $\mu \mathrm{g} \mathrm{mL}{ }^{-1}$ corresponds to the concentration of $\mathrm{NO}_{3}{ }^{-}$).

1) $500 \mu \mathrm{g} \mathrm{mL} \mathrm{L}^{-1}$ stock: $0.0407 \mathrm{~g}$ of pre-dried $\mathrm{KNO}_{3}$ was added into $50 \mathrm{~mL}$ of deionized water.

2) $100 \mu \mathrm{g} \mathrm{mL} \mathrm{m}^{-1}$ stock: $5 \mathrm{~mL}$ of the above $500 \mu \mathrm{g} \mathrm{mL}{ }^{-1}$ stock was added in a $20 \mathrm{~mL}$ volumetric flask, and add deionized water to the scale mark.

3) $0.5,0.4$ and $0.3 \mathrm{~mL}$ of $100 \mu \mathrm{g} \mathrm{mL}^{-1}$ stock solution was separately added into the test tube, to which the deionized water was then added to make up to $5.0 \mathrm{~mL}, 10,8$ and $6 \mu \mathrm{g} \mathrm{mL}^{-1}$ standard solution was finally obtained. $1 \mathrm{~mL}$ of $100 \mu \mathrm{g} \mathrm{mL} \mathrm{mL}^{-1}$ stock solution was separately added into the test tube, to which the deionized water was then added to make up to $20 \mathrm{~mL}, 5 \mu \mathrm{g} \mathrm{mL}{ }^{-1}$ standard solution was finally obtained.

4) 4, 3, 2 and $1 \mathrm{~mL}$ of $5.0 \mu \mathrm{g} \mathrm{mL} \mathrm{mL}^{-1}$ stock solution was separately added into the test tube, to which the deionized water was then added to make up to $5.0 \mathrm{~mL}, 4,3,2$ and $1 \mu \mathrm{g} \mathrm{mL}^{-1}$ standard solution was finally obtained. 

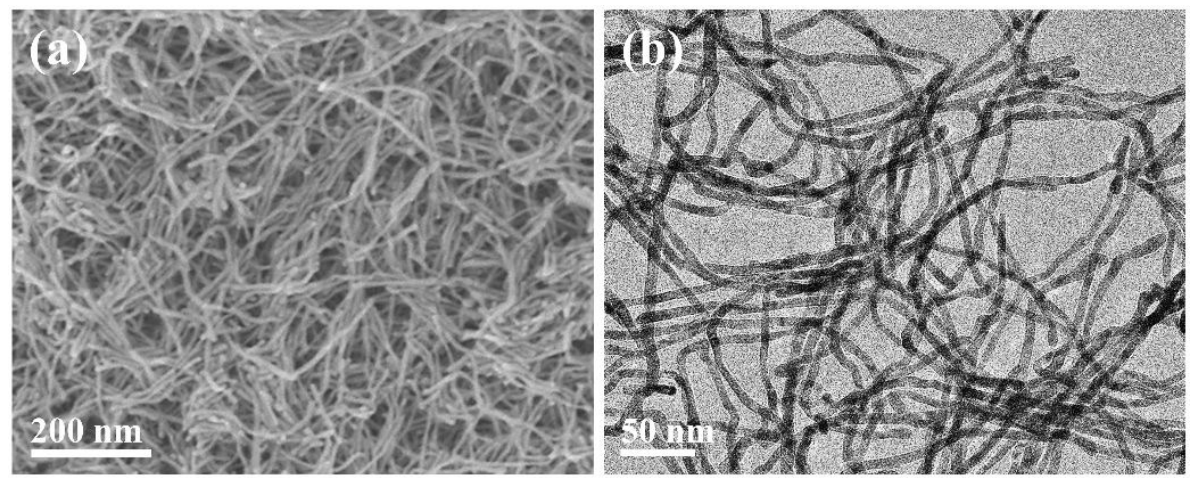

Figure S1. (a, b) SEM and TEM images of the Au NWs.

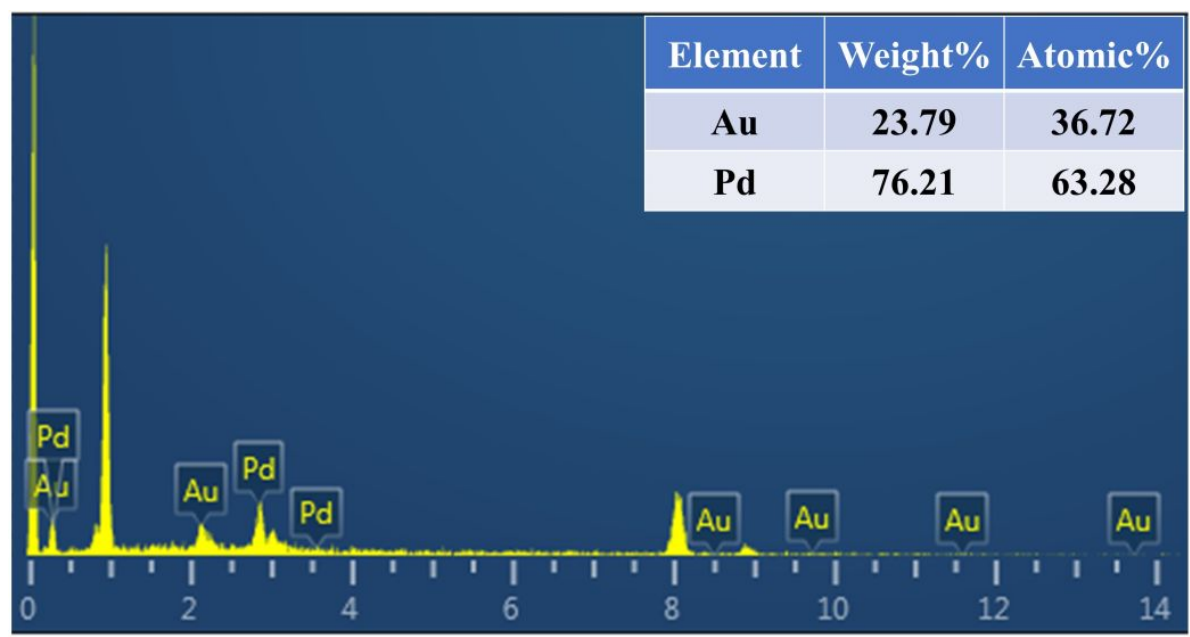

Figure S2. EDX spectrum of the AuPd NSs. 


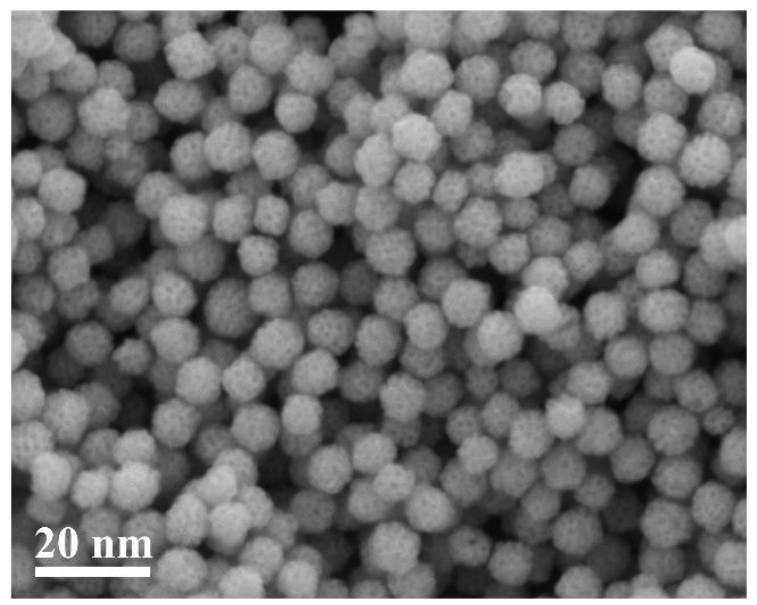

Figure S3. SEM image of the mPd NPs.

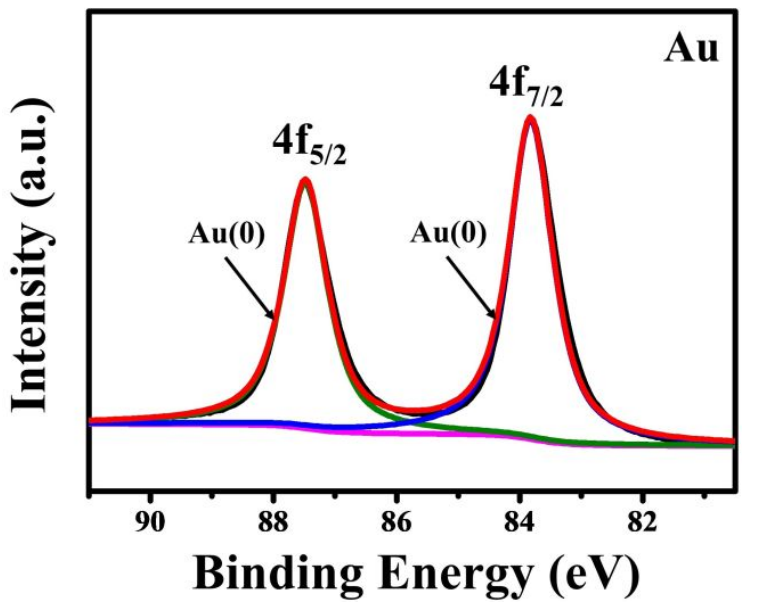

Figure S4. XPS spectrum of $\mathrm{Au} 4 \mathrm{f}$ for the $\mathrm{Au}$ NWs. 

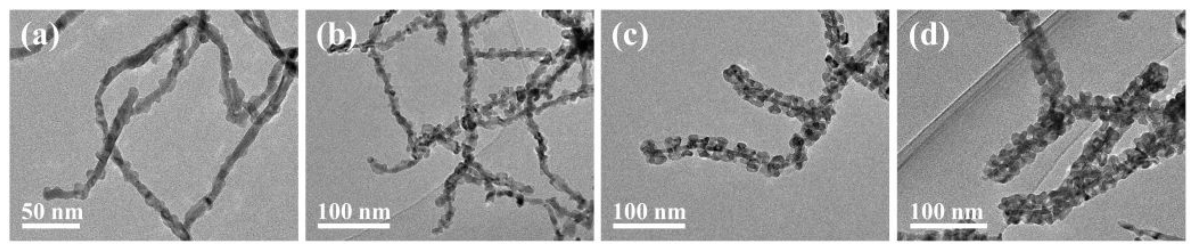

(e)
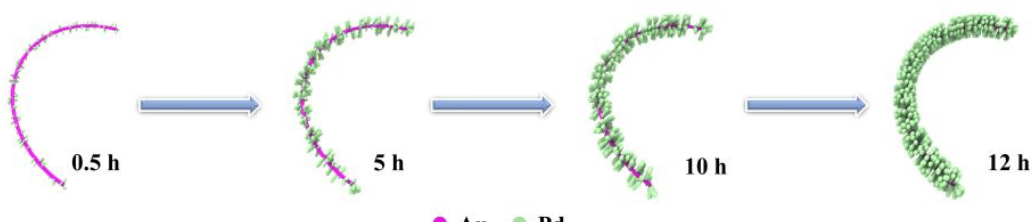

Figure S5. (a-d) TEM images of AuPd NSs at different time: (b) $0.5 \mathrm{~h}$, (c) $5 \mathrm{~h}$, (d) $10 \mathrm{~h}$ and (e) $12 \mathrm{~h}$, respectively. (e) Schematic diagram of AuPd NSs growth process.
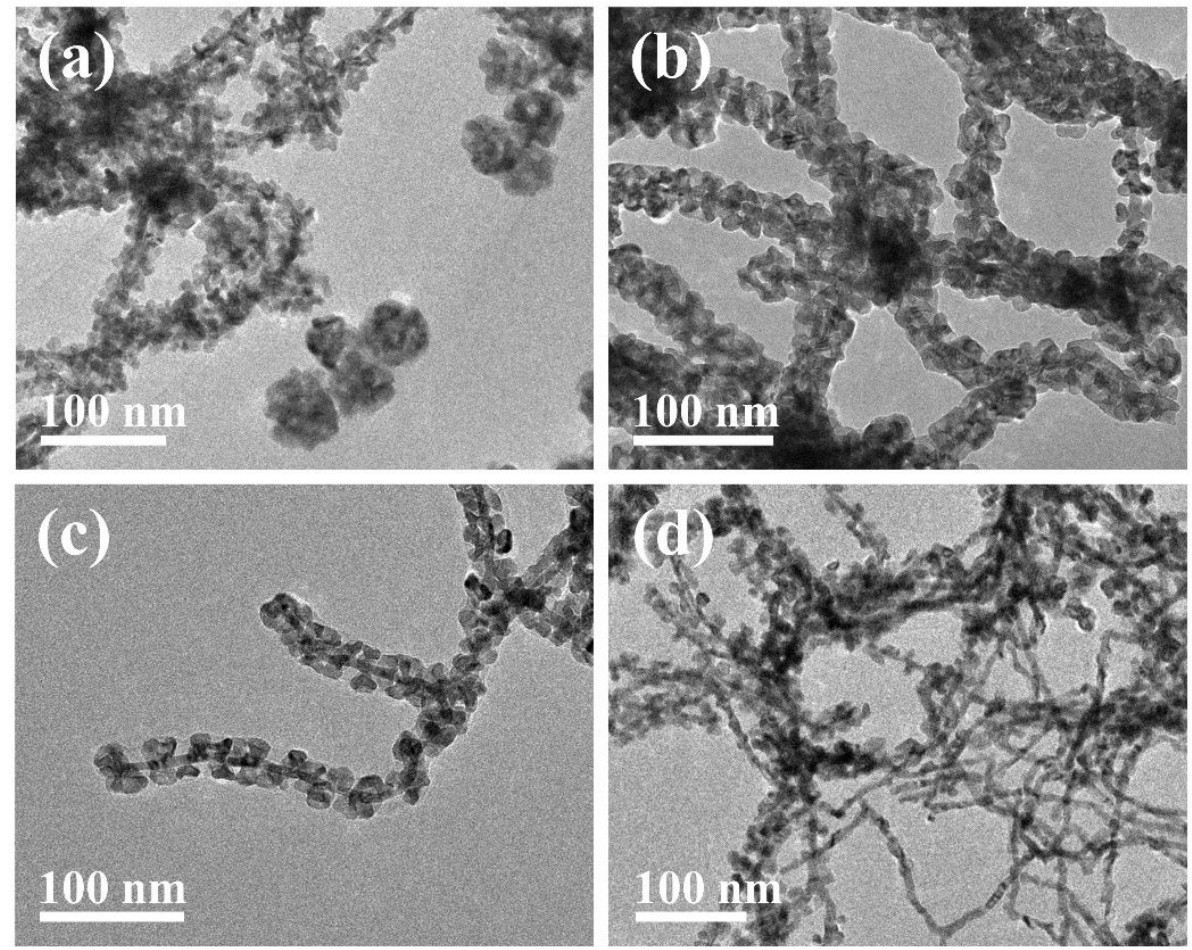

Figure S6. TEM images of the samples prepared with different amount of Au NWs: (a) $10 \mu \mathrm{L}$, (b) $25 \mu \mathrm{L}$, (c) $50 \mu \mathrm{L}$ and (d) $100 \mu \mathrm{L}$, respectively. 

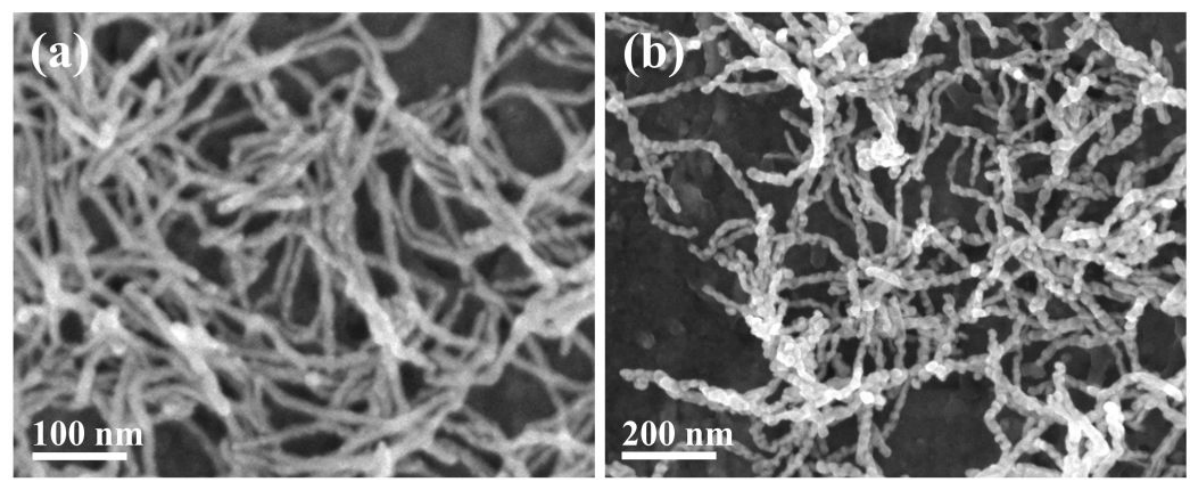

Figure S7. SEM images of the samples prepared (a) without PS-b-PEO and (b) with F127.

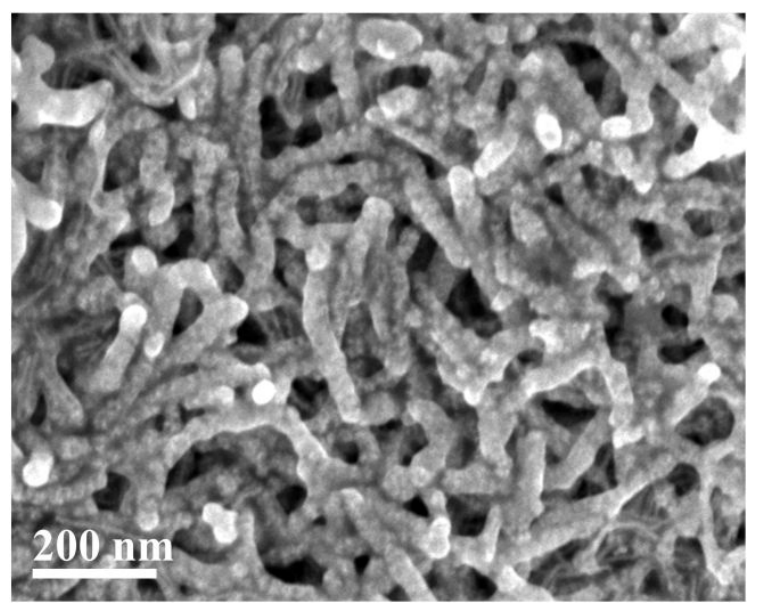

Figure S8. SEM image of the sample prepared without $\mathrm{HCl}$. 

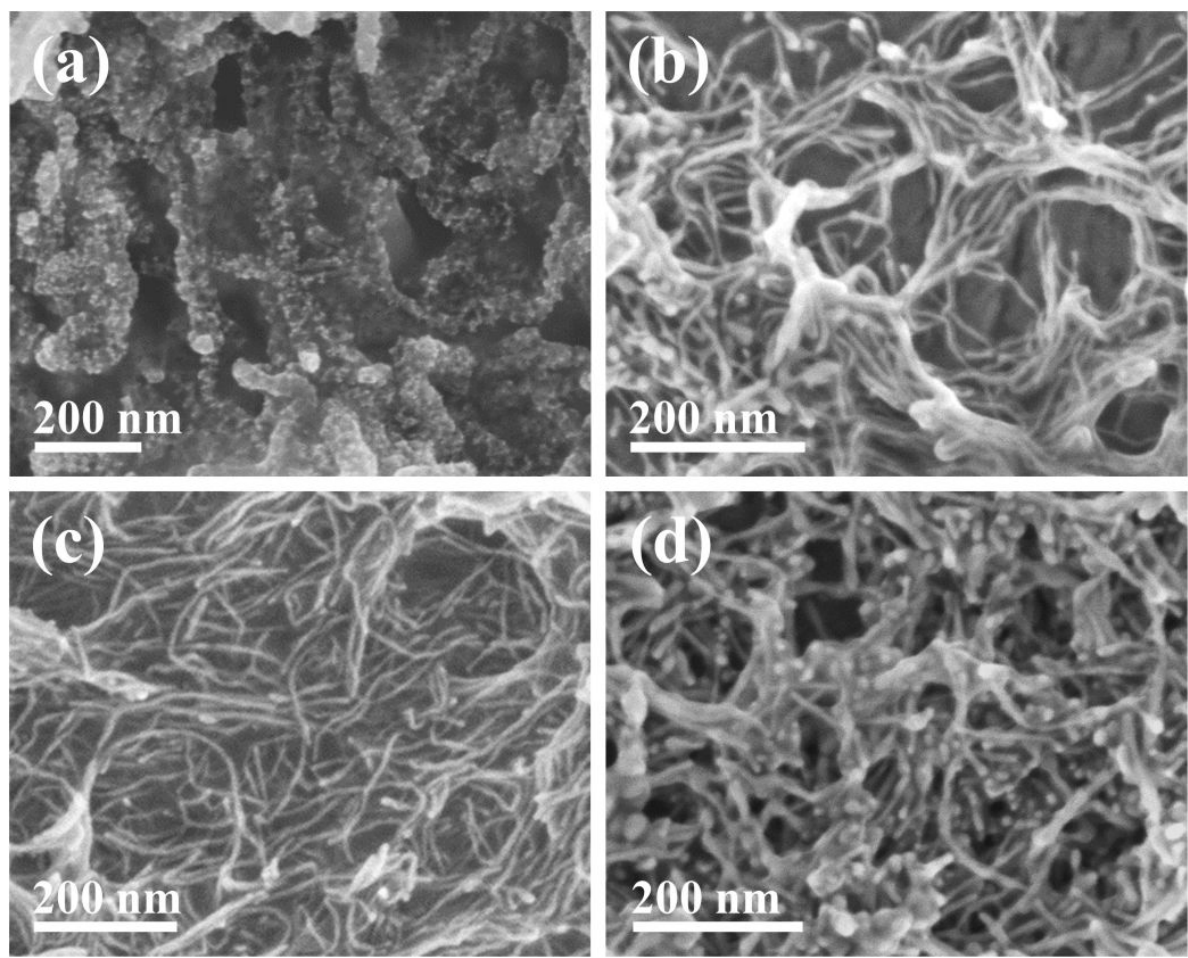

Figure S9. SEM images of the samples prepared with $\mathrm{K}_{2} \mathrm{PtCl}_{4}, \mathrm{RuCl}_{3}, \mathrm{~K}_{3} \mathrm{RhCl}_{6}$ and $\mathrm{Na}_{2} \mathrm{IrCl}_{6}$ instead of $\mathrm{Na}_{2} \mathrm{PdCl}_{4}$, respectively.
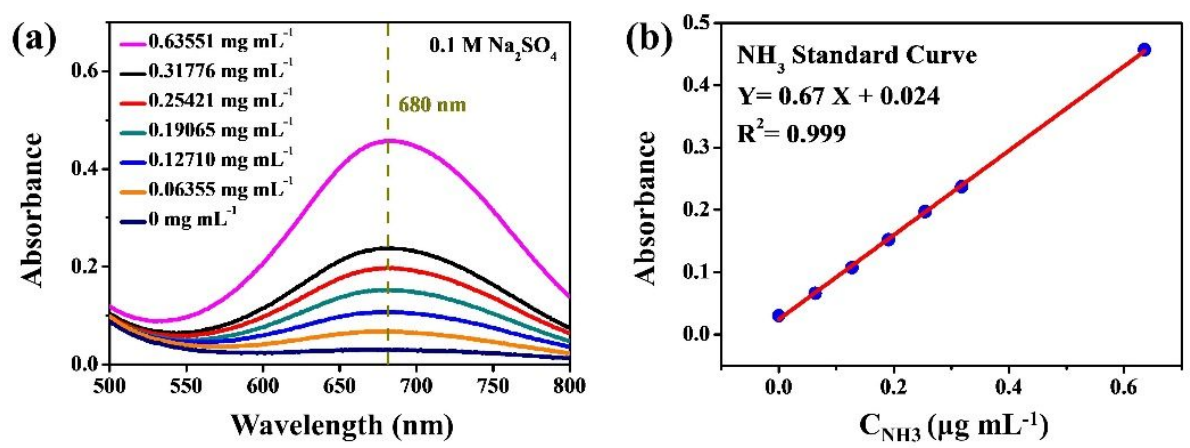

Figure S10. (a) The UV-vis absorption spectra and (b) corresponding calibration curve for the colorimetric $\mathrm{NH}_{4}{ }^{+}$assay using the indophenol blue method in $0.1 \mathrm{M} \mathrm{Na}_{2} \mathrm{SO}_{4}$. 

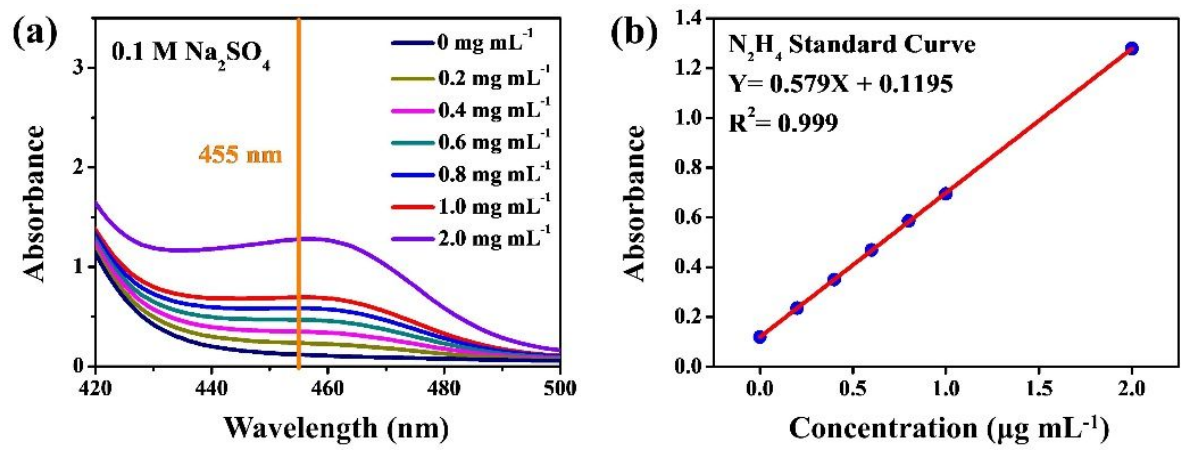

Figure S11. (a) The UV-vis absorption spectra and (b) corresponding calibration curve for the colorimetric $\mathrm{N}_{2} \mathrm{H}_{4}$ assay in $0.1 \mathrm{M} \mathrm{Na}_{2} \mathrm{SO}_{4}$.
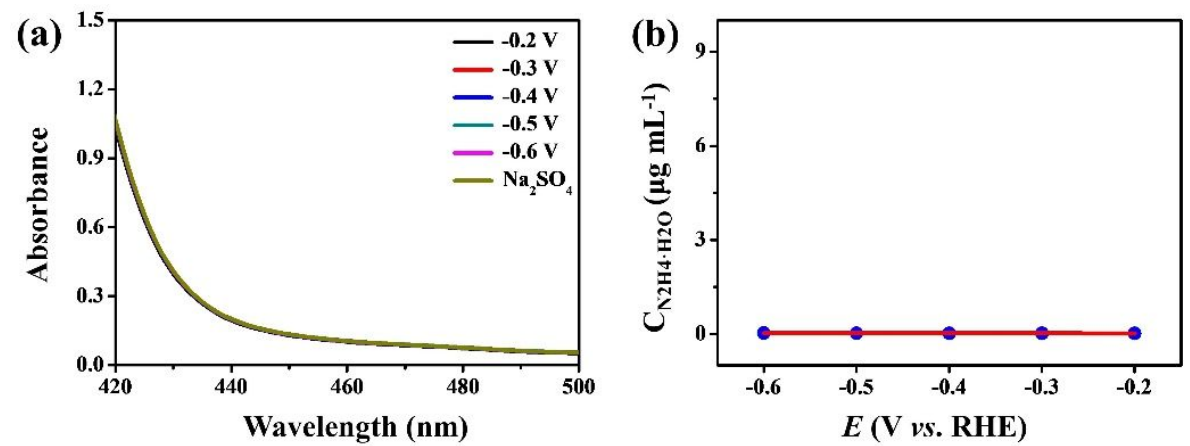

Figure S12. (a) The UV-vis absorption spectra and (b) corresponding yield rate of $\mathrm{N}_{2} \mathrm{H}_{4}$ formation at selected potentials. 

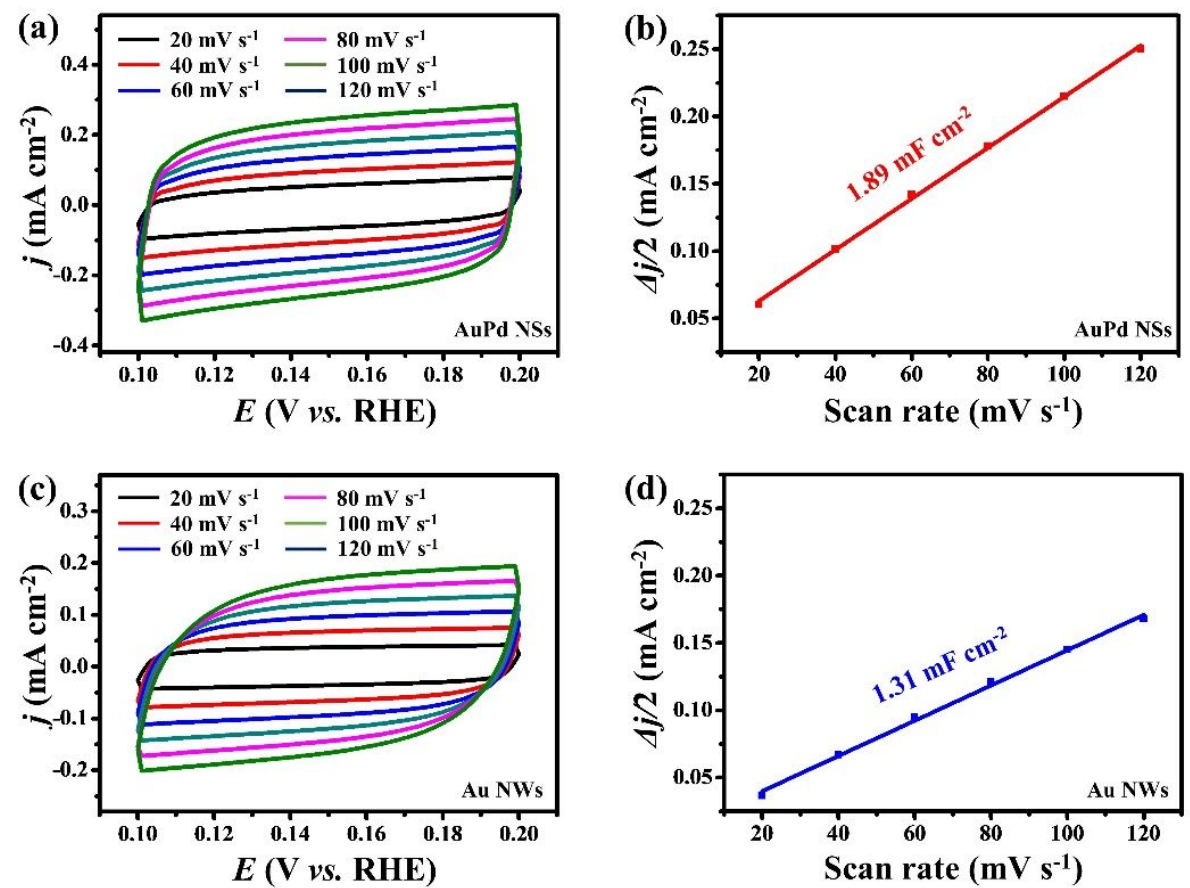

Figure S13. (a) CVs and (b) the corresponding $C_{\mathrm{dl}}$ of AuPd NSs. (c) CVs and (d) the corresponding $C_{\mathrm{dl}}$ of $\mathrm{Au}$ NWs.
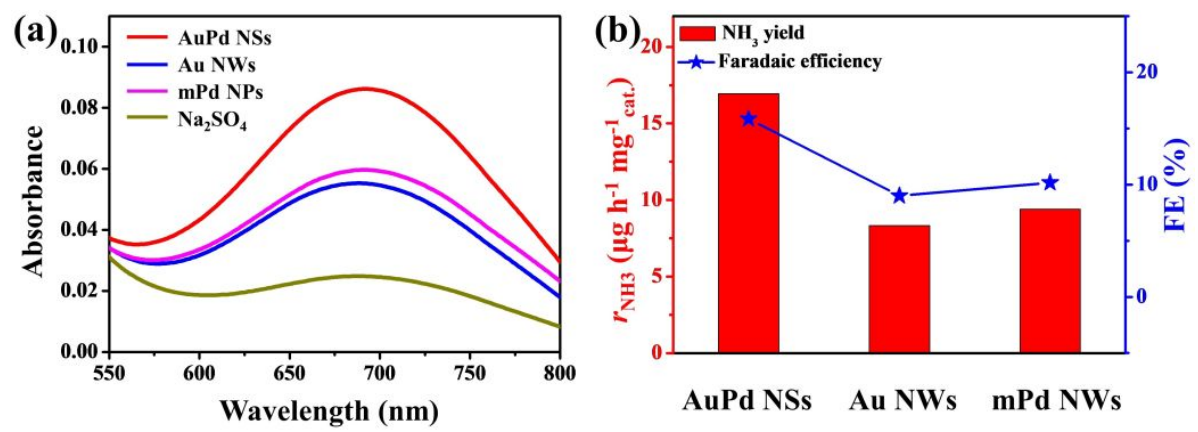

Figure S14. (a) UV-vis absorption spectra of electrolytes after electrolysis by the AuPd NSs, Au

NWs and mPd NPs at $-0.3 \mathrm{~V}$, and (b) the corresponding $/_{\mathrm{NH} 3}$ and FE. 


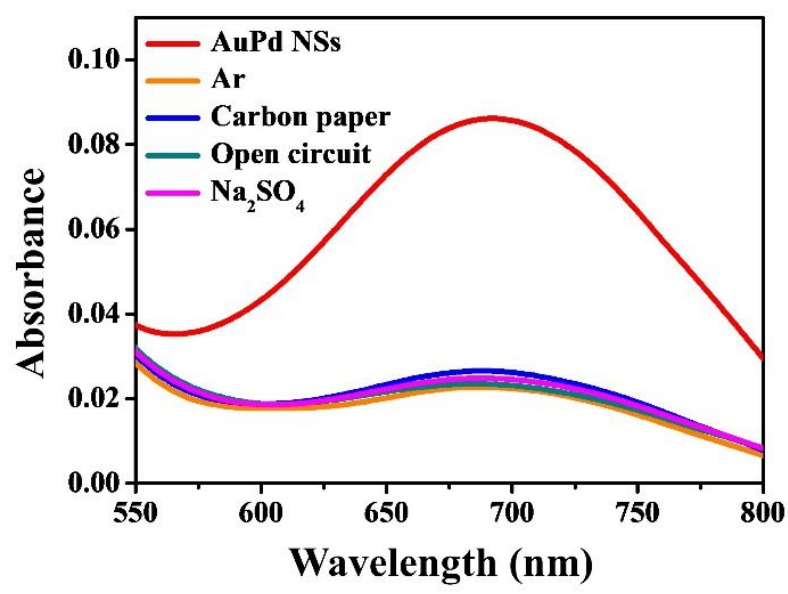

Figure S15. UV-vis absorption spectra of different solutions after electrolysis for $2 \mathrm{~h}$.
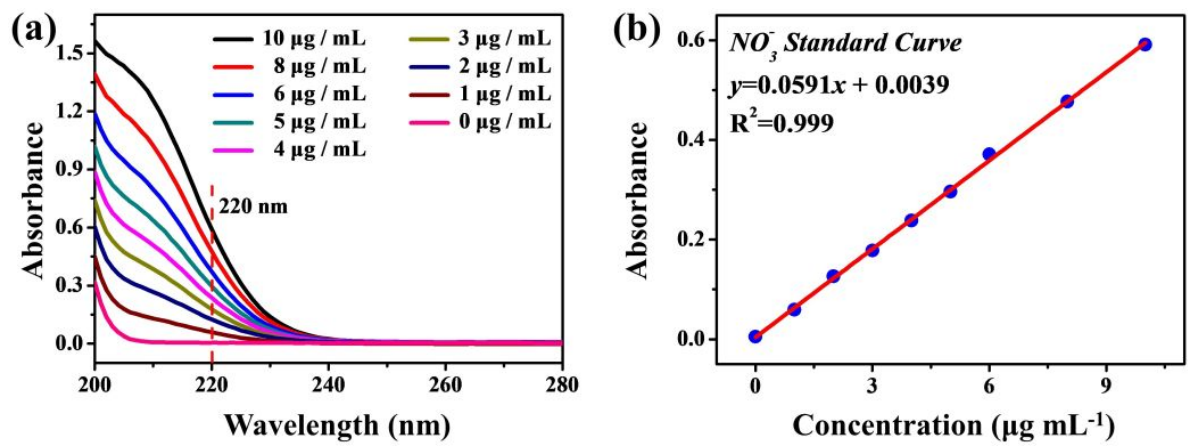

Figure S16. Calibration for nitrate determination. (a) UV-vis spectra for various concentrations of $\mathrm{KNO}_{3}$. (b) Calibration curve used for calculating the concentration of nitrate. 

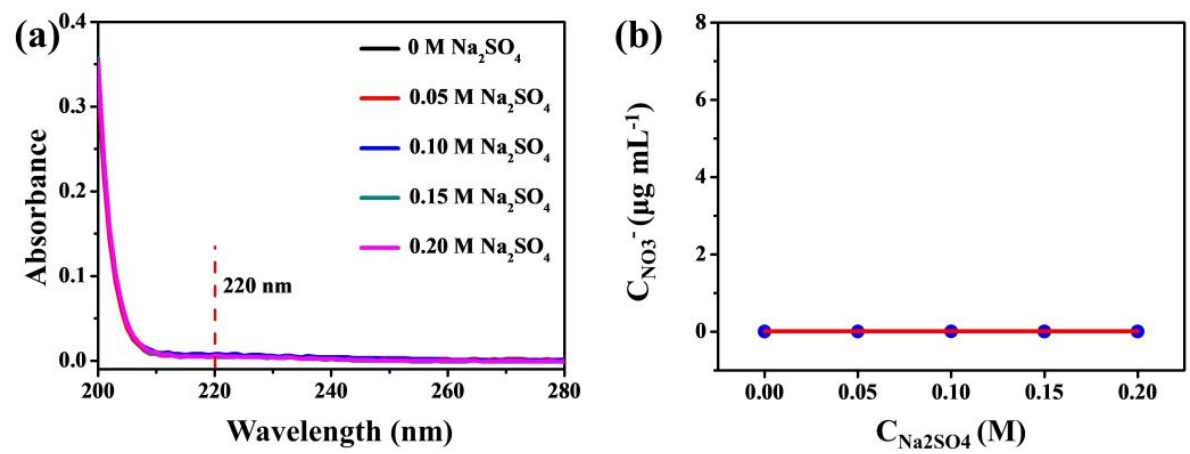

Figure S17. (a) UV spectra for determining the concentration of $\mathrm{NO}_{3}^{-}$in $\mathrm{Na}_{2} \mathrm{SO}_{4}$. (b)The concentration of $\mathrm{NO}_{3}{ }^{-}$in various concentrations of $\mathrm{Na}_{2} \mathrm{SO}_{4}$.

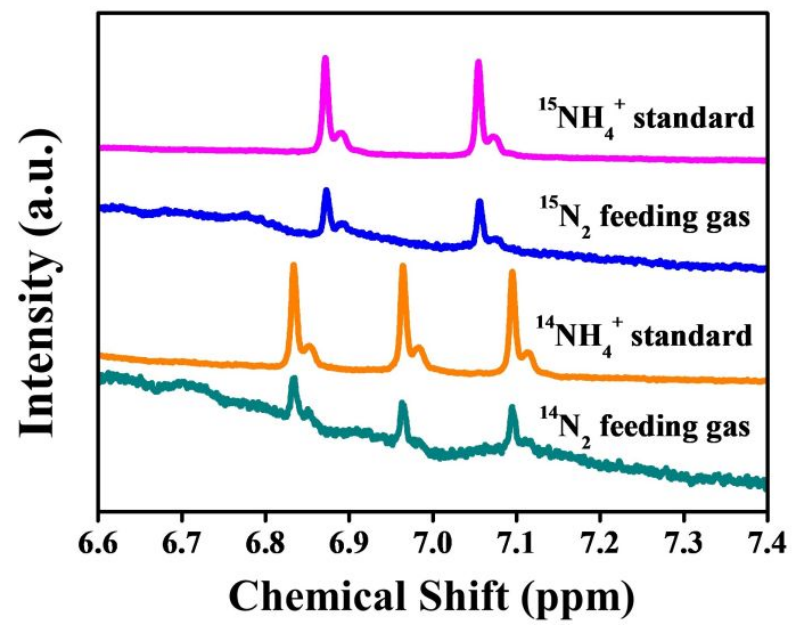

Figure S18. ${ }^{1} \mathrm{H}-\mathrm{NMR}$ spectra of both ${ }^{15} \mathrm{NH}_{4}{ }^{+}$and ${ }^{14} \mathrm{NH}_{4}{ }^{+}$produced from NRR process using ${ }^{15} \mathrm{~N}_{2}$ and ${ }^{14} \mathrm{~N}_{2}$ as the feed gas, respectively. 

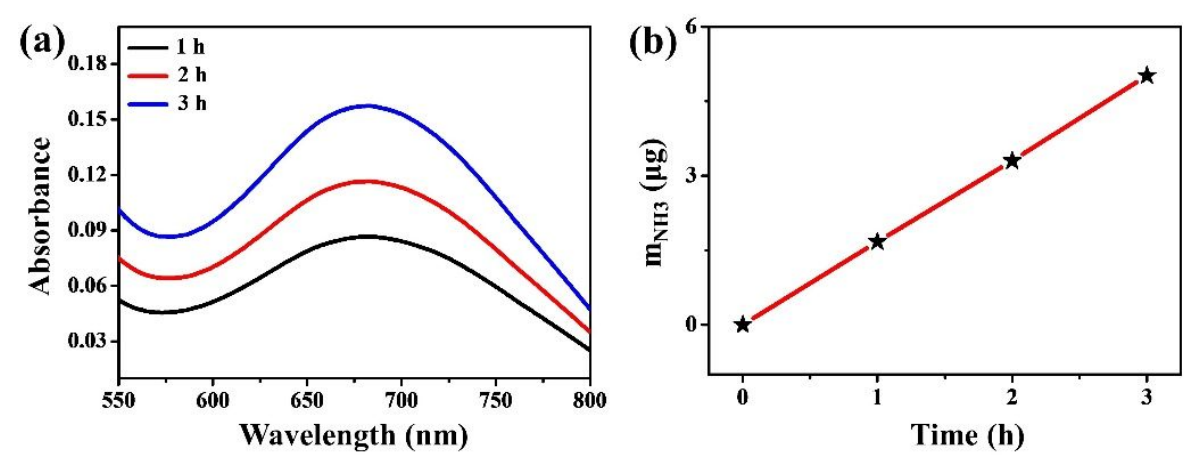

Figure S19. (a) UV-vis absorption spectra of electrolytic solutions at different reaction times. (b) Curve of $\mathrm{NH}_{3}$ production $v s$. reaction time at $-0.3 \mathrm{~V}$ over AuPd NSs.

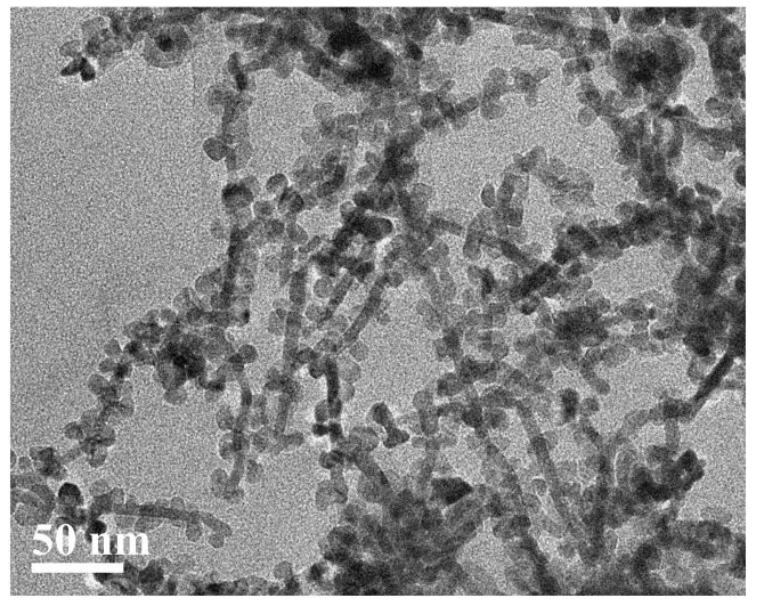

Figure S20. SEM image of the AuPd NSs after cyclic stability testing. 
Table S1. Comparisons of the NRR performance of AuPd NSs with other reported electrocatalysts.

\begin{tabular}{|c|c|c|c|c|}
\hline Catalysts & Electrolyte & $\mathrm{NH}_{3}$ yield & FE $(\%)$ & Ref. \\
\hline AuPd NSs & $0.1 \mathrm{M} \mathrm{Na}_{2} \mathrm{SO}_{4}$ & $\begin{array}{c}16.9 \mu \mathrm{g} \mathrm{h}^{-1} \mathrm{mg}^{-1} \text { cat. } \\
6.78 \mu \mathrm{g} \mathrm{h}^{-1} \mathrm{~cm}^{-2}\end{array}$ & 15.9 & This work \\
\hline 3D Pd-Ag-S PNSs & $0.1 \mathrm{M} \mathrm{Na}_{2} \mathrm{SO}_{4}$ & $9.73 \mu \mathrm{g} \mathrm{h}^{-1} \mathrm{mg}^{-1}$ cat. & 18.41 & 2 \\
\hline $\mathrm{nPd} / \mathrm{NF}$ & $0.1 \mathrm{M} \mathrm{Na}_{2} \mathrm{SO}_{4}$ & $18.27 \mu \mathrm{g} \mathrm{h}^{-1} \mathrm{mg}^{-1}$ cat. & 10.36 & 3 \\
\hline Pd-TA & $0.1 \mathrm{M} \mathrm{Na}_{2} \mathrm{SO}_{4}$ & $24.12 \mu \mathrm{g} \mathrm{h}^{-1} \mathrm{mg}^{-1}$ cat. & 9.49 & 4 \\
\hline S/Au NWs & $0.1 \mathrm{M} \mathrm{Na}_{2} \mathrm{SO}_{4}$ & $8.416 \mu \mathrm{g} \mathrm{h}^{-1} \mathrm{~cm}^{-2}$ & 15.34 & 5 \\
\hline AuPdP NWs & $0.1 \mathrm{M} \mathrm{Na}_{2} \mathrm{SO}_{4}$ & $18.78 \mu \mathrm{g} \mathrm{h}^{-1} \mathrm{mg}^{-1}$ cat. & 15.44 & 6 \\
\hline $\mathrm{AuCuB}$ PNSs & $0.1 \mathrm{M} \mathrm{Na}_{2} \mathrm{SO}_{4}$ & $13.2 \mu \mathrm{g} \mathrm{h}^{-1} \mathrm{mg}^{-1}$ cat. & 12.78 & 7 \\
\hline Ag Film & $0.1 \mathrm{M} \mathrm{Na}_{2} \mathrm{SO}_{4}$ & $1.27 \mu \mathrm{g} \mathrm{h}^{-1} \mathrm{~cm}^{-2}$ & 7.36 & 8 \\
\hline $\mathrm{Bi}^{0}$ nanoparticles & $0.1 \mathrm{M} \mathrm{Na}_{2} \mathrm{SO}_{4}$ & $3.25 \mu \mathrm{g} \mathrm{h}^{-1} \mathrm{~cm}^{-2}$ & 12.11 & 9 \\
\hline $\mathrm{Fe}_{3} \mathrm{O}_{4} / \mathrm{Ti}$ & $0.1 \mathrm{M} \mathrm{Na}_{2} \mathrm{SO}_{4}$ & $3.43 \mu \mathrm{g} \mathrm{h}^{-1} \mathrm{~cm}^{-2}$ & 2.6 & 10 \\
\hline $\mathrm{MoS}_{2} / \mathrm{CC}$ & $0.1 \mathrm{M} \mathrm{Na}_{2} \mathrm{SO}_{4}$ & $4.94 \mu \mathrm{g} \mathrm{h}^{-1} \mathrm{~cm}^{-2}$ & 1.17 & 11 \\
\hline
\end{tabular}




\section{References}

(1) Li, L. Q.; Tang, C.; Yao, D. Z.; Zheng, Y.; Qiao, S.-Z. Electrochemical Nitrogen Reduction: Identification and Elimination of Contamination in Electrolyte. ACS Energy Lett. 2019, 4 (9), 2111-2116, DOI: 10.1021/acsenergylett.9b01573.

(2) Wang, H.; Liu, S.; Zhang, H.; Yin, S.; Xu, Y.; Li, X.; Wang, Z.; Wang, L. Three-Dimensional Pd-Ag-S Porous Nanosponges for Electrocatalytic Nitrogen Reduction to Ammonia. Nanoscale 2020, 12 (25), 13507-13512, DOI: 10.1039/d0nr02884c.

(3) Wang, Z.; Dai, Z.; Yu, H.; Zhang, H.; Tian, W.; Xu, Y.; Li, X.; Wang, L.; Wang, H. Pore-Size-Tuned Pd Films Grown on Ni Foam as an Advanced Catalyst for Electrosynthesis of Ammonia. ACS Sustainable Chem. Engineer. 2020, 8 (31), 11827-11833, DOI: 10.1021/acssuschemeng.0c04295.

(4) Deng, G.; Wang, T.; Ali Alshehri, A.; Alzahrani, K. A.; Wang, Y.; Ye, H.; Luo, Y.; Sun, X. Improving the Electrocatalytic $\mathrm{N}_{2}$ Reduction Activity of $\mathrm{Pd}$ Nanoparticles through Surface Modification. J. Mater. Chem. A 2019, 7 (38), 21674-21677, DOI: 10.1039/c9ta06523g.

(5) Wang, H.; Yang, D.; Liu, S.; Yin, S.; Yu, H.; Xu, Y.; Li, X.; Wang, Z.; Wang, L. Amorphous Sulfur Decorated Gold Nanowires as Efficient Electrocatalysts toward Ambient Ammonia Synthesis. ACS Sustainable Chem. Eng. 2019, 7 (24), 19969-19974, DOI: 10.1021/acssuschemeng.9b05542.

(6) Wang, H.; Yang, D.; Liu, S.; Yin, S.; Yu, H.; Xu, Y.; Li, X.; Wang, Z.; Wang, L. Metal-Nonmetal One-Dimensional Electrocatalyst: AuPdP Nanowires for Ambient Nitrogen Reduction to Ammonia. ACS Sustainable Chem. Eng. 2019, 7 (18), 15772-15777, DOI: 10.1021/acssuschemeng.9b04092.

(7) Wang, Z.; Niu, J.; Xu, Y.; Wang, L.; Wang, H.; Liu, H. Effects of AuCuB Catalysts with Porous 
Nanostructures on Electrosynthesis of Ammonia. ACS Sustainable Chem. Eng. 2020, 8 (33), 12588-12594, DOI: 10.1021/acssuschemeng.0c03970.

(8) Ji, L.; Shi, X.; Asiri, A. M.; Zheng, B.; Sun, X. Nanostructured Bromide-Derived Ag Film: An Efficient Electrocatalyst for $\mathrm{N}_{2}$ Reduction to $\mathrm{NH}_{3}$ under Ambient Conditions. Inorg. Chem. 2018, 57 (23), 14692-14697, DOI: 10.1021/acs.inorgchem.8b02436.

(9) Yao, D.; Tang, C.; Li, L.; Xia, B.; Vasileff, A.; Jin, H.; Zhang, Y.; Qiao, S. Z. In Situ Fragmented Bismuth Nanoparticles for Electrocatalytic Nitrogen Reduction. Adv. Energy Mater. 2020, 10 (33), DOI: 10.1002/aenm.202001289.

(10) Liu, Q.; Zhang, X.; Zhang, B.; Luo, Y.; Cui, G.; Xie, F.; Sun, X. Ambient $\mathrm{N}_{2}$ Fixation to $\mathrm{NH}_{3}$ Electrocatalyzed by A Spinel $\mathrm{Fe}_{3} \mathrm{O}_{4}$ Nanorod. Nanoscale 2018, 10 (30), 14386-14389, DOI: $10.1039 / \mathrm{c} 8 \mathrm{nr} 04524 \mathrm{k}$.

(11) Zhang, L.; Ji, X.; Ren, X.; Ma, Y.; Shi, X.; Tian, Z.; Asiri, A. M.; Chen, L.; Tang, B.; Sun, X. Electrochemical Ammonia Synthesis via Nitrogen Reduction Reaction on a $\mathrm{MoS}_{2}$ Catalyst: Theoretical and Experimental Studies. Adv. Mater. 2018, 30 (28), e1800191, DOI: 10.1002/adma.201800191. 